\title{
Eksistensi Dan Partisipasi Lsm Di Indonesia
}

\author{
Jusmadi Sikumbang, SIL, M.S \\ (Staf Pengajar Fakultas Hukum USU)
}

\begin{abstract}
Abstrak
LSM adalah suatu badan yang didirikan seseorang atau sekelompok orang guna membantu masyarakat agar mandiri dan lepas dari cengkeraman kebodohan dan kemiskinan. Dalam usaha memerangi kebodohan dan kemiskinan tersebut LSM mempunyai 4 strategi yaitu amal dan derma, pengembangan masyarakat, memperjuangkan adanya perubahan kebijakan serta mendorong timbulnya gerakan kemasyarakatan. Untuk menjalankan 4 strategi tersebut dalam konteks Indonesia mengalami pasang surut. kuantitas dan kualitasnya selalu berubah-ubah tergantung dari situasi dan kondisi negara dan bagaimana proses pemerintahan di dalam rangka bernegara dan berbudaya dijalankan oleh aparatur negara. Untuk jangka panjang dikhawatirkan pimpinan dan staf LSM akan kehilangan landasan moral karena "kebanjiran due dari negara lembaga donor.
\end{abstract}

Kata Kunci : Kepemimpinan, Swadaya, Pembangunan, Pembaruan. 


\section{Latar Belakang}

Di zaman modern. dengan makin meningkatnya pendidikan dan tingkat pendapatan terutama ketika terjadi ketidakpuasan di lapisan masyarakat barn mulai timbul gejala baru dalam demokrasi yaitu Partisipasi. Dalam sejarah Barat, pertisipasi timbul dari bawah, dikalangan masyarakat yang gelisah. Gejala itu yang dilihat Alexis de Toequeville (19805 - 1959) seorang pengamat sosial Perancis dalam kunjungan ke Amerika pada tahun 30 abad 19 yakni timbulnya perhimpunan sukarela (h'ohottaly association).

Selain menyelenggarakan kepentingan mereka sendiri, dengan melakukan berbagai kegiatan inovatif, perkumpulan dan perhimpunan itu juga bertindak sebagai lembaga pengimbang terhadap kekuatan negara (as a counter to state power) Perkumpulan dan asosiasi itulah yang kemudian menjadi sokoguru "masyarakat" (civil society). Dan apa yang disebut oleh Toequeville itu tak lain dan tak bukan adalah Lembaga Swadaya Masyarakat (LSM), yang dalam masyarakat Barat modern dewasa ini disebut sebagai non government organization (NGO), (organisasi non pemerintah) dan perkumpulan sukarela (voluntary association) (Dewan Rahadjo, dalam Zaim Saidi, 1995 : xviii - xviii)

Dalam persepektif sejarah, dan mengacu pada beberapa pembagian kegiatan, dapat dilacak pula perkembangan LSM di Indonesia. Ada yang berpendapat bahwa cikal bakal LSM di Indonesia telah ada sejak masa pra kemerdekaan. Ini lahir dalam bentuk lembaga keagamaan, dan sifatnya adalah lembaga sosial atau amal. Organisasi yang di kelola oleh kaum agamawan, seperti Syarikat Islam, Muhammadiyah dalam kalangan Islam atau kelompok para zending Katolik/Protestan.

Baru pada tahun 50-an tercatat muncul LSM yang kegiatannya bersifat alternative terhadap program pemerintah. Dua pelopornya, misalnya adalah LSD (Lembaga Sosial Desa) dan Perkumpulan Keluarga Kesejahteraan Sosial.

Keduanya menjadi unsur yang menonjol, atas dasar pertimbangan kemanusiaan dan kedermawanan.

Pada tahun 60-an terjadi perkembangan lebih jauh lagi, ditandai dengan kelahiran beberapa lembaga, yang bergerak terutama dalam pengembangan pedesaan. Pendekatan dengan proyek-proyek mikro menjadi ciri utama masa kini, terutama yang menyangkut aspek sosial ekonomi pedesaan. Pada kurun ini pula lembaga-lembaga ini merintis

jaringan kerjasama nasional, misalnya lahir Yayasan Sosial Tani Membangun, yang kemudian hari berkembang menjadi Bina Desa dan Bina Swadaya. (Zaim Saidi 1995 :78)

Ciri LSM muncul dan berkembang pada tahun 70-an menunjukan hal yang lain lagi. Ini dipengaruhi masa Orde Baru, dan boleh dikatakan, LSM merupakan reaksi sebagian anggota masyarakat atas kebijakan pembangunan yang ditempuh oleh Orde Baru.

Dasar penggeraknya adalah motivasi untuk mempromosikan peran serta dan keterlibatan masyarakat dalam pembangunan. Meskipun masih juga berorientasi 
pada proyek mikro, LSM generasi 1970-an ini mulai mengaitkannya dengan persoalan kebijakan pada tingkat makro. Contohnya LSM yang lahir pada generasi ini LP3ES, LBH, YLKI, LSP dan sebagainya (Zaim Saidi, 1995 : 8)

Pengertian LSM itu sendiri muncul di Indonesia pada akhir tahun 1970-an. Jadi bukan sejak awal adanya kegiatan kemasyarakatan itu sendiri. Istilah ini merupakan pengganti dari istilah sebelumnya, yaitu Organisasi Non Pemerintah (Ornop), yang merupakan terjemah langsung dari istilah Non Government Organization (NGO). Perubahan istilah ini dilakukan karena, di satu sisi ada kesan dan anggapan bahwa istilah Ornop memiliki konotasi negatif, yaitu seakan-akan sebagai lawan pemerintah.

Eksistensi dan partisipasi NGO asing di Indonesia Nampak nyata pada waktu Indonesia mendapat musibah tsunami di Aceh dan Nias pada tahun 2004 disamping itu, program-program pendidikan untuk masyarakat Indonesia ke luar negeri banyak juga dibiayai oleh NGO asing, dan sampai sekarang masih berlanjut.

Di dalam hukum positif Indonesia, LSM dikenal untuk pertama kalinya di dalam Undangundang No. 4 Tahun 1982 tentang

Ketentuan-ketentuan Pokok Pengelolaan Lingkungan Hidup. Menurut Undang-Undang LSM adalah organisasi yang tumbuh secara swadaya, atas kehendak dan keinginan sendiri, di tengah masyarakat, dan berminat serta bergerak dalam bidang lingkungan hidup. (Pasal 1 ayat 12 U.U.No.4

Tahun 1982).

Selanjutnya Undang-Undang ini menyatakan bahwa setiap orang mempunyai hak dan kewajiban untuk berperan serta dalam rangka pengelolaan lingkungan hidup (Pasal 16 ayat 1). Sedangkan LSM berperan sebagai penunjang bagi pengelolaan lingkungan hidup (Pasal 19).

Dengan keluarnya U.U. No. 23 Tahun 1997 Tentang Pengelolaan Lingkungan Hidup maka U.U No. 4 Tahun 1982 tidak berlaku lagi. Sedangkan istilah LSM di dalam undang-undang yang barn ini tidak ada lagi, diganti dengan sebutan Organisasi Lingkungan Hidup. (Pasal 1 angka 22, U.U. No. 23 Tahun 1997). Mengapa LSM begitu cepat popular dan cepat diterima masyarakat? Para Pendukung LSM menunjuk pada keunggulan yang dimiliki LSM di bandingkan dengan jenis organisasi lain. Goran Hyden misalnya, menggambarkan keunggulan-keunggulan ini secara rinci :

- The First is that NGOs are much closer than the government to the poorer section of society

- The second is that NGOs staff are normally higly motivated and altruistic in their behavior

- The third is that NGOs operate economically

- The fort advantage of NGOs is their flexibility a guality that stems from small size and the decentralized nature of decision making structures.

- The fifth advantage is the independence of the NGO from government which gives an opportunity to develop demans 
for public services and resourees and thus facile trite the wirk of individual government department is la rurd arcos (Goran Hyden, 1983: 120-121)

Lima keunggulan tersebut diatas dapat diterjemahkan sebagai berikut :

1. LSM dekat dengan kaum miskin dan mempunyai organisasi terbuka yang memudahkan pengeluaran informasi ke atas.

2. Mempunyai staff yang bermotifasi tinggi

Di pihak lain, di kalangan aktivis saat itu, ada kesadaran bahwa gerakan mereka ini dilandasi dengan suatu misi positif, yakni mengembangkan kemandirian dan keswadayaan. Tidak semata-mata "bukan pemerintah". Dengan alasan itu tepatnya dalam satu lokarya yang diadakan oleh Bina Desa, April 1978, di Ungaran istilah LSM muncul menggantikan istilah Ornop. (Zaim Saidi, 1995:9).

Dalam kurun waktu dua dekade terakhir, perkembangan LSM di Indonesia terjadi dengan sangat pesat. Jumlah dan jenisnya semakin beragam; demikian Pula kegiatannya makin meluas. Namun, seperti telah disinggung diatas, popularitasnya yang meningkat tidak berarti

mencerminkan pemahaman masyarakat atasnya yang semakin baik.

Yang patut diketahui bahwa sebutan NGO itu sendiri-untuk

kelompok-kelompok dalam masyarakat yang demikian itu datangnya dari kalangan pemerintah. Secara formal, misalnya, dalam skala3. internasional istilah ini dibakukan oleh PBB, dalam salah satu resolusi Ecosoc, yang kemudian memberikan status dan akreditasi untuk mengikuti berbagai kegiatan lembaga pemerintah ini.

Dengan formalisasi itu, dapat dikatakan paham non governmentalism telah menjadi bagian dari sistem pemerintahan secara utuh, dalam sistem demokrasi. Artinya dalam setiap proses pengambilan keputusan sektor non pemerintah ini selalu dilibatkan, tanpa membedakan visi dan misi masing-masing kelompok itu.

Di negara-negara Eropa Barat atau Amerika, NGO disebut-sebut sebagai pilar ke-4 demokrasi, disamping tiga pilar lainnya yakni eksekutif, yudikatif, legislative. Implikasi lain dan keadaan ini seperti yang bisa dilihat di negara-negara Barat itu, adalah bahwa negara

mengalokasikan sebagian dari anggaran belanjanya untuk kegiatan sektor non pemerintah itu.

Pada tingkat internasional untuk mengakomodasikan keterlibatan NGO ini, PBB secara khusus memfasilitasi berdirinya satu lembaga penghubung yaitu UN Non

Governmental Liaison Serviee (NGLS). Badan ini didirikan pada tahun 1975, dan merupakan penghubung NGO dengan sistem multilateral PBB. Peran utamanya adalah membantu NGO dalam kegiatannya, khususnya pendidikan, advokasi, analisis kebijakan, dan proses negosiasi yang mempengaruhi negara maju dan negara sedang berkembang NGLS dibiayai oleh badan dan Program PBB. (Zaim Saidi, 1995:10)

Membiayai kegiatannya secara ekonomis dan efisien.

4. LSM cukup kecil, terdesentralisasi, luwes dan mampu menerima 
umpan balik dari proyek yang dikerjakan.

5. LSM lebih mampu untuk mendorong penggunaan jasa-jasa pemerintah yang lebih banyak.

MenurutPeterHagul (1985:185) LSM nampaknya ingin menonjolkan sekurang lima ciri sebagai identitasnya yaitu :

1. Dapat menjangkau penduduk termiskin.

2. Mendorong partisipasi yang lebih luas.

3. Tidak birokratis

Sedangkan Glen Williams (198011) mengemukakan 3 karakteristik LSM :

1. Organisasi dibentuk bukan atas inisiatif pemerintah dan berorientasi non-profit.

2. Bebas dari pemerintah dan organisasi lainnya dalam menyusun prioritas kegiatannya.

3. Membatasi kegiatannya terutama padakesejahteraansosial, kesehatan,pendidikandan pembangunan kemasyarakatan. Sehubungan dengan semakin tumbuh dan berkembangnya LSM dan organisasi kemasyarakatan lainnya, maka pemerintah merasa perlu mengaturnya dalam satu

Peraturan berbentuk UndangUndang. Undang-undang tersebut adalah U.U. No. 8 Tahun 1985 Tentang Organisasi kemasyarakatan dan sebagai peraturan pelaksanaannya pemerintah mengeluarkan Peraturan Pemerintah No. 18 tahun 989.

Salah satu pertimbangan mengapa Undang-undang tentang organisasi kemasyarakatan tersebut diberlakukan adalah:
"Bahwa organisasi kemasyarakatan sebagai sarana untuk menyalurkan pendapat dan pikiran bagi anggota masyarakat warga negara Indonesia, mempunyai peranan yang sangat penting dalam meningkatkan keikutsertaan secara aktif seluruh lapisan masyarakat dalam mewujudkan masyarakat Pancasila berdasarkan UndangUndang Dasar 1945 dalam rangka menjamin pemantapan persatuan dan kesatuan bangsa, menjamin keberhasilan pembangunan nasional sebagai pengalaman Pancasila, dan sekaligus menjamin tercapainya tujuan nasional". (Konsideran U.U.No.8 Tahun 1985 huruf e).

Sedangkan Intruksi Menteri Dalam Negri No. 8 Tahun 1990 dan Surat Keputusan Bersama Menteri Dalam Negeri dan Menteri Sosial No 78 Tahun 1993 dan No 39/HUKJ1993 Tentang Pembinaan LSM adalah ketentuan yang dibuat sebagai kelanjutan dari U.U. No. 8 Tahun 1985 dan P.P No. 18 Tahun 1986.

Instruksi Mendagri No. 8 Tahun 1990 memuat Intruksi Mendagri kepada Gubernur , Bupati/Walikota Kepala Daerah di seluruh Indonesia agar dapat melakukan inventarisasi dan pembinaan terhadap LSM yang berada di wilayahnya. Disamping itu diinstruksikan juga pada Gubernur dan Bupati/Walikota untuk dapat mengadakan koordinasi dengan instansi lain yang terkait di daerah yang mempunyai wewenang dan kepentingan dengan bidang kegiatan LSM yang bersangkutan. 


\section{II}

LSM telah menjadi aktor dipanggung pembangunan lebih panjang daripada Bank Dunia, PBB atau badan-badan resmi pemberi dana lainnya sampai dengan beberapa waktu yang lalu mereka hanya memainkan peran minor-hasil kerjanya sangat baik tetapi secara keseluruhan tidak terkait langsung dengan plot. Selama dasawarsa 1980an situasi ini berubah. Mereka telah beranjak kearah pusat panggung (John Clark, 1995 : 3). Peningkatan peran LSM terjadi ketika konsep pembangunan dari aktor yang lebih mapan, agen-agen pembangunan yang resmi menemui kegagalan. Pembangunan seperti yang mereka defenisikan tidak terwujud (John Clark, 1995 :4).

Aktor pembangunan yang penting sejak berakhirnya PD. II adalah badan-badan internasional, khususnya Bank Dunia dan PBB dan lembaga-lembaga bantuan dart negara-negara Utara seperti US Agency For International Development (USAID). Seluruh badan-badan internasional ini mengembangkan suatu model pembangunan yang seringkali kurang sensitive terhadap kebutuhan masyarakat banyak dan masalah lingkungan.

Model pembangunan mereka memang lebih menfokus pada produksi kekayaan daripada distribusi kekayaan, produksi ekspor daripada kebutuhan lokal, ektrasi sumber daya alam daripada pelestarian lingkungan, dan teknologi model Barat, misalnya disektor pertanian sering kali menambahkan masalah atau krisis (John Clark, 1995 :4)

Pada penghujung abad XX, jumlah, LSM meningkatkan dengan sangat luar biasa. Jumlahnya secara pasti masih belum diketahui. Ada yang mengatakan sekitar 500-an, ada pula yang mengatakan lebih dari 1000. Jumlah itu masih dianggap tidak memadai, diperkirakan jumlah LSM di seluruh Indonesia tiga kali lebih banyak dari angka-angka yang telah dikemukakan diatas. (Amir E. Siregar : 1988:29).

Selanjutnya sebuah survey yang dilakukan oleh Fachri Ali, menyebutkan bahwa sekitar $57 \%$ dari LSM di lahirkan dalam 10 tahun terakhir, dan sekitar 29,2\% didirikan diantara 11 dan 20 tahun terakhir ini Kurang lebih $71 \%$ dari pendirinya adalah pribadi-pribadi (Amir E. Siregar, 1988:29).

Peter Hannam (1998: 7-8) dalam penelitiannya di Indonesia mengemukakan beberapa ciri Pimpinan dan Staf sebagai aktor penggerak LSM.

1. Pimpinan dan staf LSM umumnya tamatan Universitas. Bahkan pimpinannya ada vane tamatan luar negeri.

2. Pimpinan LSM pada umumnya bermotivasi tinggi dan idealistis, sedangkan staf LSM kebanyakan bergabung di LSM hanya demi memperoleh pekerjaan.

3. Pimpinan LSM sangat dinamis dan bersemangat wirausaha.

4. Dominasi pimpinan membuat pembuatan keputusan cenderung tersentralisir sehingga kesempatan staf untuk berpartisipasi cenderung terbatas. 
5. Dominasi pimpinan yang sentralistis membuat sulit memelihara semangat staf dalam organisasi.

6. Karena partisipasi staf sangat terbatas, maka LSM menjadi terlalu tergantung dengan pimpinan.

7. Pimpinan LSM yang karismatik dan biasa dominan jarang mau menuruti pimpinan LSM lainnya.

Mengenai masalah

kepemimpinan, David Brown, Ketua Lembaga Penelitian Pembangunan di Boston, mengidentifikasikan adanya dilema kepemimpinan yang melekat dalam struktur LSM, dicirikan dengan 2 tipe kepemimpinan LSM yang berbeda:

1. Seorang karismatik memiliki komitmen dan visi yang dalam yang digerakkan oleh inspirasi dan kualitas personalnya tetapi tetap mempertahankan struktur yang tidak jelas dan cenderung agak diktator dalam pengambilan keputusan. Secara tipikal mereka ini adalah para pendiri LSM itu.

2. Pemimpin Kolegial, yaitu pimpinan yang memiliki komitmen besar terhadap partisipasi, yang berbagi pengaruh dan fungsi dengan staf

lain dan yang suka akan pengambilan keputusan yang dilakukan melalui proses kolegial, didalam suatu struktur manajemen yang ketat. (Dawid L Brown dalani John Clark, 1995:71)

Judith Tendler telah menunjukkan bahwa sebuah factor umum yang terdapat. di banyak yang berhasil adalah adanya kepemimpinan karismatik (Judith Teadler dalam John Clark, 1995:71)
Dua gaya kepemimpinan karismatik dan kolegial, keduanya memiliki kelemahan.

Mencari keseimbangan yang benar antara kepemimpinan kuat yang dapat menjamin dengan tegas pencarian gagasan kuat, dan gaya keterbukaan yang menjamin seluruh perasaan staf dinilai dengan sebagaimana mestinya adalah merupakan tantangan manajemen yang paling besar bagi

LSM, terutama pada saat organisasinya sedang tumbuh. Ini merupakan salah satu sebab dari perpecahan di beberapa organisasi (John Clark, 1995:73)

Kepemimpinan dan staf sebagaimana yang dikemukakan di ataslah yang menjadi aktor penggerak LSM Indonesia. Aktor- aktor ini pula yang berhubungan dengan aktor LSM lainnya, baik yang ada di dalam maupun yang berada di luar negeri. Lembaga Donor dari negara-negara maju (Utara) juga selalu berhubungan dengan pemimpin LSM baik

karismatik maupun kolegial sebagaimana aktor penggerak LSM.

Untuk Indonesia

kepemimpinan karismatik lebih diakui, lebih dominan, dan karenanya mudah berhubungan, baik ke dalam maupun keluar negeri. Sayangnya aktor model karismatik ini sebagaimana yang dirumuskan Peter Hannarn yang dikutip diatas jarang mau menuruti pimpinan LSM nya.

Disamping itu, masalah kepemimpinan juga membuat LSM Indonesia "patah tumbuh hilang berganti, gugur satu muncul seribu" dan ini jugalah yang membuat sulit 
membuat data tumbuh dan berkembangnya LSM Indonesia.

Menurut John Clark (1995:73), dibawah kepemimpinan karismatik staf berada pada posisi yang lemah. Ada suatu kecenderungan untuk merekrut staf yang akan menuruti dan merasa takut kepada pemimpin. Seluruh gagasan barn berasal dari satu sumber yakni sang pemimpin, yang kurang mendapat dorongan ataupun gagasan kreatif dari para koleganya. Dalam situasi semacam ini, LSM tidak mendapat nilai penuh dari para stafnya, atau mungkin mereka tidak memberi struktur karir lebih jauh lagi.

Oleh karena banyaknya kelemahan di dalam kepemimpinan LSM Indonesia, diperlukan suatu sistem yang dapat membuat proses pemilih kepemimpinan LSM lebih demokratis. Untuk ini diharapkan adanya "kemauan politik" dari pemimpin yang berkuasa (memimpin).

Anggaran dasar dan anggaran rumah tangga atau kode etik LSM harus dibuat sedemikian rupa dimana proses demokrasi di dalam menjalankan roda organisasi dapat lebih dikedepankan. Antara lain dapat dikemukakan disini adalah:

1. Masa jabatan pemimpin terbatas.

Dibatasi satu periode tertentu misalnya.

2. Prosespemilihan pemimpin demokratis.

3. Adanya sistem baku di dalam proses perekrutan staf LSM.

4. Manajemen terbuka dan pertanggung jawabanya harus jelas.

5. Koordinasiyang mengarah regenerasi.

\section{III}

David Korten, seorang aktivis dan penganut LSM, memberikan perkembangan LSM. Ia membagi LSM menjadi empat generasi berdasarkan strategi yang dipilihnya. Generasi pertama mengambil peran sebagai pelaku langsung dalam mengatasi persoalan masyarakat.

Pendekatannya adalah derma, dengan usaha untuk memenuhi sesuatu yang kurang dalam masyarakat, misalnya kebutuhan

akan kesehatan, makanan. pendidikan, dan sebagainya. Generasi ini disebut sebagai relief and welfare LSM generasi ini memfokuskan keeiatan pada kegiatan amal untuk anggota masyarakat. Generasi kedua memusatkan perhatian pada upaya agar LSM dapat mengembangkan kemampuan Masyarakat untuk memenuhi kebutuhan mereka sendiri peran LSM disini bukan sebagai pelaku langsung, tetapi sebagai penggerak saja. Orientasi kegiatannya adalah pada proyek-proyek pengemba- ngan masyarakat. Generasi ini disebut sebagai small scale. Self reiliance local development.

LSM generasi ini melihat masalah sosial dengan lebih kompleks. Tidak sekedar melihat soal yang langsung kelihatan saja, tapi mencari akar sebabnya dan mengkaitkannya dengan soal kebijakan pembangunan. Fokus kegiatannya ada pada upaya membantu masyarakat untuk memecahkan masalah mereka. Sebagai misal adalah program peningkatan pendapatan, industry kerajinan, pertanian, teknologi tepat dan sebagainya. Semboyan yang popular adalah berilah: pancing, dan bukan ikannya. 
Generasi ketiga memiliki pandangan yang lebih jauh. Keadaan di tingkat lokal dilihat sebagai akibat dari masalah regional atau nasional. Masalah mikro dalam masyarakat tidak dipisahkan dengan masalah politik pembangunan nasional, Karena itu penanggulangan mendasar dilihat hanya dimungkinkan kalau ada perubahan struktural. Kesadaran seperti itulah yang tumbuh pada LSM generasi ini bersamaan dengan otokritiknya atas LSM generasi sebelumnya sebagai "pengrajin sosial" LSM generasi ini sebagai sustainable system development.

Generasi keempat adalah LSM yang. termasuk bagian dari gerakan masyarakat dan disebut sebagai people movement. Generasi ini berusaha agar ada transformasi struktur sosial dalam masyarakat dan di setiap sektor pembangunan yang mempengaruhi kehidupan. Visi dasarnya adalah citacita terciptanya dunia barn yang lebih baik. Karena itu

dibutuhkan keterlibatan umum penduduk dunia. Ciri gerakan ini dimotori oleh gagasan dan bukan organisasi yang terstruktur. (david Korten dalam Zaim Saidi, 1995:6)

Mengenai konsep LSM generasi keempat, David Korten lebih lanjut menjelaskan:

"Konsep generasi LSM keempat adalah mengenai LSM yang menjadi pendorong timbulnya suatu gerakan kemasyarakatan. Suatu gerakan kemasyarakatan adalah gerakan yang dimotori oleh suatu gagasan, bukan suatu organisasi yang struktur. Contoh awal yang baik dari suatu gerakan kemasyarakatan adalah James Yen (pelopor Gerakan Rekontruksi Pedesaan di Asia), di
Cina 1930-an, yang mengembangkan suatu metode untuk melawan kebuta hurufan masyarakat dengan memperkenalkan suatu sistem karakter yang lebih sederhana. Dalam mendorong perluasan gerakan ini, tidak ada anggaran atau organisasi yang tersentralisasi. Yang berperan hanya sebuah gagasan. Dalam dunia yang lebih kontemporer terdapat gerakan-gerakan lingkungan hidup dan perlindungan konsumen yang juga didasari oleh suatu gagasan. Secara ringkas, LSM generasi keempat adalah organisasi yang mengartikulasi gagasan yang bergetar dalam sanubari orang banyak atau dengan kata suatu gagasan yang waktunya sudah tepat. Suatu

$\begin{array}{rr}\text { persyaratan } & \text { bagi } \\ \text { perkembangan } & \text { LSM }\end{array}$
keempat ini adalah masyarakat yang lebih terbuka. Jika keterbukaan masyarakat tidak hadir, gerakan kemasyarakatan yang berkembang dapat menjadi gerakan kemasyarakatan yang destruktif, karena tampil sebagai reaksi terhadap kontrol. Saya pikir kita dapat mengamati kemunculan di dunia LSM tingkat global benih- benih dari gerakan yang berpusat pada demokratisasi adalah sangat esensial bagi kemajuan pembangunan di setiap tempat. Di masa datang, mungkin kita akan menyaksikan keterkaitan antara LSM-LSM di Asia, Amerika Latin, Afrika dan mungkin LSM negaranegara Utara, dalam memperjuangkan ruang gerak yang lebih besar dalam masyarakat, dalam menciptakan sistem pemerintahan lebih terbuka, dan untuk mendapatkan pengakuan pemerintah terhadap arti penting inisiatif lokal. 
Ini memang harus menjadi suatu prioritas dalam setiap agenda pembangunan. Jika LSM-LSM dunia berkumpul, tema demokratisasi ini tampak menjadi tema umum, meskipun gerakan kemasyarakatan untuk demokratisasi ini masih dalam tahap-tahapnya yang paling awal (David Korten, 1988:62)"

$\mathrm{Ke}$ empat generasi yang dikemukakan David Korten tersebut diatas (charity, development, advocacy dan people movement) dalam konteks Indonesia mengalami pasang surut. Kwantitas dan kualitasnya selalu berubah-ubah tergantung dari situasi dan kondisi negara dan bagaimana proses pemerintahan dalam rangka bernegara dijalankan oleh operator negara.

Dewasa ini ada semacam pengakuan yang hampir mendekati taraf universal yaitu bahwa pengentasan kemiskinan, pemberantasan kelaparan, proteksi lingkungan, pembangunan masyarakat bawah dan membantu negara miskin dari krisis utang merupakan prioritas. Akan tetapi

pengalaman agen-agen resmi pembangunan mengenai masalahmasalah ini amatlah terbatas atau mempunyai banyak kendala operasional oleh sebab itu mereka lalu berusaha menjalin hubungan LSM di Utara maupun Selatan (John Clark, 1995:5)

Pengakuan ini sebagaimana yang dikemukakan John Clark tersebut diatas melahirkan banyak LSM baik di Utara (negara maju) maupun di Selatan (negara miskin/berkembang). Aktivitas LSM tersebut beraneka ragam sesuai dengan strategi sebagaimana yang dikemukakan David Korten, sayangnya banyak kendala yang, harus dihadapi LSM di dalam rangka memperluas peran pembangunan LSM.

Menurut David Korten :

"Salah satu kendala serius untuk memperluas peran pembangunan LSM mungkin adalah kesulitan yang mereka hadapi dalam menjalin kerjasama diantara mereka. Kecemburuan diantara mereka sering kali amat kuat, dan upaya untuk menyatukan semuanya kerapkali terpecah ke dalam permusuhan yang melumpuhkan upaya kerjasama untuk mencapai tujuan bersama. Ironisnya, pada suatu saat adalah lebih mudah bekerjasama dengan pemerintah daripada dengan LSM lain." (David Korten dalam John Clark, 1995:101)

Disadari atau tidak, diakui atau tidak

LSM menjadi penting karena saluran formal seperti partai dan parlemen sudah tidak berfungsi lagi. LSM menjadi hidup karena pemain lain mati.

Oleh karena di Indonesia telah terjadi perubahan besar (lengsernya Soeharto pada Mei 1998) maka LSM mau tidak mau harus menciptakan Paradigma barn di dalam usaha pemberdayaan masyarakat. Strategi "terobosan", "memanfaatkan peluang", "alternatif, bermain dalam aturan yang ada" yang merupakan bagian dari siasat yang dijalankan LSM dalam menghadapi rejim Orde Baru saat sekarang ini hares "disesuaikan" dengan situasi dan kondisi era reformasi. 
Krisis ekonomi yang dihadapi Pemerintah jelas membuat pemerintah tidak bisa memenuhi semua kebutuhan pokok masyarakat. Segala sesuatunya menjadi mahal. Angka kemiskinan terus meningkat dan karenanya aktivitas yang bersifat karitatif hares terus berlanjut. Aktivitas yang bersifat karitatif ini tidak mungkin hanya dilakukan oleh pemerintah saja, tetapi tidak ada salahnya jika LSM ikut dilibatkan.

Kerjasama antara pemerintah dengan LSM diharapkan \&Qat mengembangkan kemampuan masyarakat untuk memenuhi kebutuhan mereka sendiri. Peran LSM disini bukan sebagai pelaku langsung, tetapi sebagai penggerak saja. Hal ini sesuai dengan strategi generasi kedua LSM sebagaimana yang dikemukakan David Korten generasi disebut sebagai small scale, sself reliance local development.

Untuk ke depan jika pemerintah tetap taat asas strategi generasi LSM yang pertama dan kedua sebagaimana yang

dikemukakan David Korten lah yang banyak berperan. Kecuali jika pemerintah selalu membuat kebijakan yang bertentangan dengan kepentingan rakyat banyak (miskin), jika hal ini yang terjadi maka strategi generasi LSM yang ketiga yang akan lebih banyak berperan yaitu generasi LSM yang bersifat advocacy. Kami berpendapat demikian karena kami melihat bahwa LSM itu dibentuk adalah untuk:

1. Menentang segala bentuk penindasan dan ketidak adilan baik itu elit lokal, pemerintah negara atau pun lembaga-lembaga asing dari negara maju.

2. Memainkan satu peran kritis.
3. Membangun jaringan warga dunia secara global untuk melakukan tekanan.

4. Mempelajari dan menggambar-kan bagaimana krisis kon-temporer mempengaruhi orang miskin.

5. Melakukan eksperimen pendeka-tan baru dalam menghadapi krisis.

6. Dapat menjadi pelopor atau katalis bagi aksi pemerintah.

7. Dapat menyampaikan pesan-pesan yang berguna bagi pemberdayaan masyarakat melalui media massa.

Sedangkan generasi strategi LSM yang ke empat yaitu people movement sangat berperan jika pembangunan yang dilakukan pemerintah menimbulkan dampak negative bagi rakyat, atau pembangunan digunakan hanya bisa berjalan ditempat.

Hal ini pasti menimbulkan masalah. Masalah yang kemungkinan besar dihadapi bangsa Indonesia adalah yang berkaitan dengan lingkungan hidup, Perlindungan konsumen, pertahanan (ganti rugi) dan masalah lapangan kerja (pengangguran) dan korupsi.

Masalah-masalah tersebut akan sangat mempengaruhi timbulnya suatu gagasan dan atau gerakan kemasyarakatan (people movement) sebagaimana dikemukakan David Korten dalam konsep LSM generasi keempatnya.

Oleh Karena proses demokrasi dan demokratisasi sudah berjalan cukup siginifikan, persoalan demokrasi dan demokratisasi menurut hemat kami tidak menjadi masalah, kecuali sistem pemerintahan kembali lagi ke sistem pemerintahan rezim orde baru yang otoriter. 
Gagasan mengenai perlu adanya proteksi yang serius terhadap lingkungan hidup serta perlindungan yang berkelanjutan terhadap konsumen dan kemudian adanya usaha yang terus menerus di dalam penyelesaian masalah tanah (ganti rugi) serta usaha pengadaan lapangan kerja untuk mengatasi pengangguran akan terus berkembang sejalan dengan derap langkah pembanguan itu sendiri.

Apabila gagasan tersebut diatas tidak di tumbuh kembangkan atau tidak ada usaha untuk menggerakkan masyarakat agar sadar akan masalahmasalah yang sedang dan akan dihadapi maka akan timbul :

1. Kecemasan yang berhubungan dengan degredasi lingkungan dan banyaknya dipergunakan bahanbahan kimia sintetis yang tidak dapat dicerna secara alami yang merupakan bahan berlangsung berbahaya

2. Konflik di masyarakat yang berkaitan dengan penguasaan lahan dan konflik yang berkepenjangan yang menyangkut besar kecilnya ganti rugi tanah.

3. Kecemasan terhadap penyakit masyarakat yang timbul akibat banyaknya pengangguran.

4. Kecemburuan sosial yang semakin meningkat karena perbedaan kaya-miskin, perbedaan penduduk ash dan pendatang yang berkisar pada perbedaan yang sifatnya ekonomi dan politis.

5. Korupsi dan kolusi makin merajalela dalam bentuk baru.

Untuk mengatasi masalahmasalah tersebut, LSM harus menata kembali eksistensi dan partisipasinya. Harus ada perubahan.

Konsep-konsep mengenai Pragmatisme Baru, Penyesuaian

Struktural dan Transformasi Struktural perlu dikaji secara mendalam guna mendapatkan konsep yang relevan dengan perubahan keadaan. Dengan perkataan lain LSM harus melakukan redefinisi konsep dan pemikirannya, kalau tidak LSM pasti akan ditinggalkan massanya.

LSM generasi keempat akan tumbuh dan berkembang sejalan dengan adanya masyarakat yang terbuka. Menumt David Korten sebagaimana yang telah kami kutip diatas jika keterbukaan masyarakat tidak hadir, gerakan kemasyarakatan yang berkembang dapat menjadi gerakan kemasyarakatan yang destruktif karena tampil sebagai reaksi terhadap control.

Melihat perkembangan LSM Indonesia saat sekarang ini, kesimpulan yang dapat ditarik adalah:

1. Bahwa LSM Indonesia tidak mandiri, tergantung dari bantuan pihak lain (Asing). Ini memang ironis. Bagaimana bisa membangun masyarakat mandiri, kalau belajar swadaya untuk dirinya pun tidak mampu?

2. Bahwa pimpinan dan staf LSM kebanyakan aktif di LSM karena ingin mendapatkan uang dan popularitas. Akibatnya banyak pimpinan dan staf LSM mulai terjangkiti penyakit yang dulu hendak diperanginya, seperti korupsi, kolusi dan nepotisme (KKN).

3. KeluarLSM anti statusquo.

Disamping itu banyak pimpinan 
LSM yang bertindak eksploitatif terhadap staf-stafnya.

4. Untuk jangka panjang dikhawatirkan pimpinan dan staf LSM akan kehilangan landasan moral karena "kebanjiran duit" dari negara/lembaga donor.

5. Agar LSM tidak "patah tumbuh hilang berganti-gugur satu muncul seribu" dan agar LSM tidak ditinggal stafnya, sudah saatnya dipikirkan bagaimana sebaiknya mengatasi sengketa antara Pimpinan LSM dengan stafnya, antara staf LSM dan staf LSM satu dengan LSM lainnya.

\section{DAFTAR PUSTAKA}

Amir Effendy Siregar, Pertumbuhan dan Pola Komunikasi (ISM/: PSM), Majalah prisma No. 4 Tahun 1988, LP3ES, Jakarta

Clark, John, NGO dan Pembangunan Demokrasi, PT. Tiara Wacana Yogya, Yogyakarta, 1995

Haqul, Peter, Pembangunan Desa dan Lembaga Swadaya
Masyarakat, CV. Rajawali, Jakarta 1985

Hannam, Peter, Pengembangan Bentuk Pembangunan Alternatif : Perjalanan LSM di Indonesia, Majalah prisma No. 4 Tahun 1988, LP3ES, Jakarta

Hyden, Goran, No Shortcuts to Progress University of California Press,

Berkeley, California, USA, 1983 Korten David C, LSM Generasi

Keempat : Fasilitator Gerakan Kemasyarakatan, Majalah Prisma No. 4 Tahun 1988, LP3ES, Jakarta.

Wiliiam, Glen, Community Participation and the Role off Voluntary Agencies in Indonesia, Prisma Magazine No. 16 1980, LP3ES, Jakarta.

Zaim Saidi, Secangkir Kopi Max Havelaar, LSM dan Kebangkitan Masyarakat, PT. Gramedia Pustaka Umum, Jakarta 1995. 